\title{
First report of leaf spots in Caryota mitis L. caused by Alternaria alstroemeriae in Pakistan
}

\author{
Imran UI haq ${ }^{1} \cdot$ Siddra ljaz $^{2}$ • Anjum Faraz ${ }^{1}$. Muhammad Kaleem Sarwar ${ }^{1}$. Muhammad Zunair Latif ${ }^{1}$. \\ Nabeeha Aslam Khan ${ }^{1}$
}

Received: 28 June 2019 / Accepted: 3 December 2019 / Published online: 13 March 2020

(C) Società Italiana di Patologia Vegetale (S.I.Pa.V.) 2020

Keywords Ornamental palm $\cdot$ Fungal leaf spots $\cdot$ Pathogenicity confirmation $\cdot$ Molecular characterization

Caryota mitis L. (Clustering fishtail palm) is an important outdoor ornamental palm grown in landscapes of gardens and parks. Circular brown spots with chlorotic halo, which later on became necrotic and irregular, were observed on leaves of this palm. Diseased leaves were sliced, disinfected, placed on potato dextrose (PDA) agar medium and incubated at $26^{\circ} \mathrm{C}$. Seven-day-old fungal cultures were brown to black with submerged hyphae. Conidiophores were arising from hyphae dark brown, sub erect, 2-5 septations and $3.7 \mu \mathrm{m}$ in width. Conidia in chain, were long ellipsoid, subcylidrical, with 2-6 transverse septations, no longitudinal septations and $27.8 \pm 5.7 \mu \mathrm{m}$ length, $9.7 \pm 1.3 \mu \mathrm{m}$ width in size. Based on morphology, the fungal culture was identified as Alternaria alstroemeriae (Simmons 2007). For its molecular identification, three taxonomic important loci, internal transcribed spacer region of rDNA, glyceraldehyde-3phosphate dehydrogenase (GAPDH) and RNA polymerase II second largest subunit (RPB2) were explored. DNA sequences of each investigated locus were submitted to GenBank with accession Nos. MK948016, MK950850 and MK950849, respectively. In phylogenetic hierarchy based on each locus, this fungal isolate strongly clustered with CBS 118809 strain of A. alstroemeriae. This characterized culture of A. alstroemeriae was deposited to Fungal

Imran Ul haq

imran_1614@yahoo.com

1 Fungal Molecular Biology Laboratory, Department of Plant Pathology, University of Agriculture, Faisalabad, Pakistan

2 Centre of Agricultural Biochemistry and Biotechnology, University of Agriculture, Faisalabad, Pakistan
Molecular Biology Culture Collection (FMB-CC-UAF), University of Agriculture Faisalabad, Pakistan with accession number FMB 0178 . Spore suspensions $\left(1 \times 10^{5}\right.$ concentration) of $A$. alstroemeriae were sprayed on healthy leaves of C. mitis and sterile distilled water only was sprayed on control plants to confirm the pathogenicity test using Koch's postulates. Three weeks after inoculation similar leaf spot symptoms appeared as were observed under field condition and reisolated fungal pathogen was confirmed as A. alstroemeriae. This is the first report of A. alstroemeriae causing leaf spots in C. mitis in Pakistan.

Funding information This study was funded by HEC Project \#2762.

\section{Compliance with ethical standards}

Conflict of interest All authors declare that they have no conflict of interests.

Ethical statement This article does not contain any studies with human participants or animals.

\section{Reference}

Simmons EG (2007) Alternaria, an identification manual. CBS Biodiversity Series 6:444-445 Netherlands: CBS

Publisher's note Springer Nature remains neutral with regard to jurisdictional claims in published maps and institutional affiliations. 